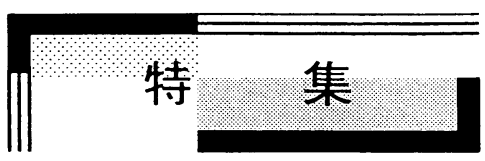

\title{
ロケット・宇宙機における推進薬管理*
}

\section{Propellant Management in Liquid Rockets and Space Vehicles}

\author{
姫 野 武 洋** \\ HIMENO Takehiro
}

\begin{abstract}
With the progress of human activities in space, the occasion to handle liquids in non-uniform acceleration or low-gravity is now growing. On the launch vehicles with liquid propulsion system, the dynamic acceleration during its powered ascent or ballistic flight makes it very difficult to control the position of propellants in the tanks. For the establishment of the technology for the management of liquid propellant in space vehicles, a numerical method, called 'CIP-LSM' (CIP based Level Set \& MARS), was developed to simulate three-dimensional free-surface flows under various gravity conditions, which has been applied to clarify the dynamic behavior of liquid propellant in the tanks of launch vehicles.
\end{abstract}

Keywords: Cryogenic, Free-surface Flow, Liquid Rocket, Propellant Management, CFD

\section{1. 緒 言}

人間の日常的な活動領域が地球周回軌道上ま で拡大寸るのに伴い、宇宙活動を支える基盤技術 として、低重力環境で燃料や泠却剤などの液体を 貯蔵そして輸送する技術は欠かせないものであ り、今後ますます重要となる。例えば、軌道上に 推進機関用の燃料を貯蔵して宇宙輸送機に供給 する技術が確立されれば、再使用が可能な軌道間 輸送機を実現でき、低コストで柔軟性に優れた宇 宙輸送体系のための基盤を構築することが期待 される。

しかし、推力や姿勢変動を伴うロケット飛翔中 の動的加速度環境や、比重差による液体駆動を期 待できず、界面張力の影響が顕在化する地球周回 軌道上の低重力環境では、自由表面流の挙動は地 上の場合と大きく異なり、液体を容器内部の望ま しい位置に保持し、思い通りに容器外部へ輸送す ることすら難しくなる。そのため、「重いものほ ど下に沈む」という、地上での経験を頼りに設計
された流体機器は、軌道上で想定した性能を発揮 できず、計画通りに運用できない恐れがある。

このように、特殊な加速度環境における自由表 面流の挙動予測と制御は、宇宙工学の分野で、「流 体管理(fluid management)」、あるいは、宇宙輸送 システムに限って、「推進薬管理 (propellant management)」と呼ばれる[1,2]。

軌道上での流体搬送技術と熱管理技術を確立 するためには、低重力環境における自由表面流の 流動と伝熱の特性を適切に評価および予測でき る知見が求められる。しかし、自然現象に潜む支 配法則を分析するだけでなく、それらの知見を総 合し、熱流動現象を制御して人工物の設計に反映 するという工学的立場からは、残念ながら、関連 する知見の蓄積は十分でない。実際、低重力環境 において種々の熱流動現象を観察する実験は精 力的に実施されているが、大気圏内で落下塔や航 空機を用いて人為的に低重力環境を創出できる 機会は設備と費用の両面から限られており、機会

\footnotetext{
* 2013.11.14 受付

** 東京大学大学院工学系研究科 $\overline{1} 113-8656$ 文京区本郷 7-3-1

TEL: (03)5841-6576 FAX: (03)5841-6624 E-mail: himeno@aero.t.u-tokyo.ac.jp
} 
に恵まれたとしても獲得できる低重力環境の質 と持続時間にかなりの制約を受ける。このことが 軌道上で運用される機器の設計段階における試 運転を難しくしており、勢い設計は保守的になら ざるを得ず、宇宙開発利用を展開していく技術の 革新と低コス卜化を阻む一要因となっている。

一方、理論的予測と実験的再現が困難な現象へ の第三のアプローチとして、系全体を有限個の要 素に分割し、要素の内部状態と相互関係を規律し た支配方程式を数值的に解くシミュレーション の援用が期待される。近年著しい計算機性能の向 上とあいまって、かっては大規模と冠された数值 解析は様々な分野の研究開発に従事する研究者 や設計部署の個人レベルでも可能となり、計算力 学という横断的な学問領域が形成されている。実 際、単相流の計算流体力学 $(C F D)$ は、理論と実験 を補完する手段として、様々な流体機械の設計に 応用されている。自由表面流の分野でも、経験的 な構成方程式やモデルをできるだけ排除した数 值解析手法の構築が試みられており [3-5]、大変形 しながら移動する気液界面を精度良く追跡でき る技術が確立されつつある。

\section{2. 自由表面流の挙動予測へ向けた接近法 \\ 2.1 数值解析手法の開発}

東京大学と宇宙航空研究開発機構(JAXA)は協 力して、宇宙輸送系の推進薬管理に関寸る基盤技 術として、無重力から地上重力まで広範な加速度 環境に置かれた自由表面流を模擬できる数值流 体解法 CIP-LSM を開発してきた。

宇宙機の推進薬タンク内部では、常温の気体と 極低温の液体がしばしば共存し、熱交換に伴う流 体粒子の体積変化を無視できないため、非圧縮流 の仮定が不適切な場合も少なくない。流動の速さ は各相の音速と比べてかなり遅く、圧縮性流体解 法を適用寸るのも難しい。伝熱現象や相変化まで も考慮するならば、温度を従属変数とせず直接的 に解くのが望ましく、熱流束をより適切に評価す るためには、界面近傍における物性值の平滑化を 避け、人工的な界面厚を極力排除したい。また、 高精度な界面追跡のためには、数值的散逸の小さ な計算スキームで対流項を評価すべきである。

本手法は、上記の要求を意識して設計されてお り、CIP-CUP 法[3]を熱流動解析用に改良した TCUP 法により均質二相流の Navier-Stokes 方程式

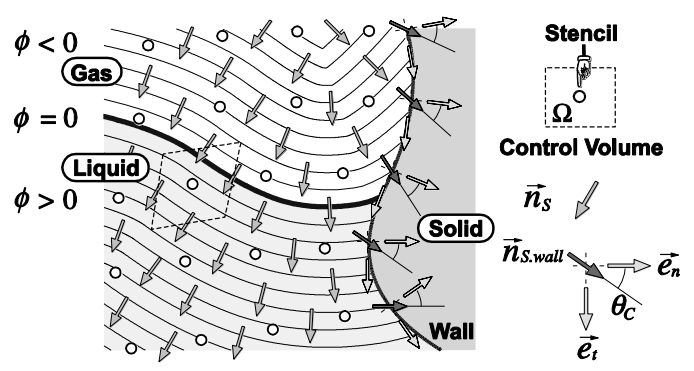

Fig.1 Interface capturing in CIP-LSM[6]. Normal vector of interface calculated from the distribution of distance function.

を解く一方、Fig.1 に示すように、MARS 法[4]と Level Set 法(LSM) [5]を融合した界面捕獲法によ り、体積保存性と形状捕捉の両方を高度に満足し つつ、大変形する液面を三次元一般曲線座標の固 定格子上で追跡できるのが特長である。計算手法 の詳細は文献[6]を参照されたい。

\section{2 検証実験の実施}

数值解法の開発と並行して、微小重力環境で界 面張力に駆動される流れを観察する落下塔実験 や、再使用ロケット内部のスロッシングを想定し た模型タンクの加振実験も実施している。一連の 研究の狙いは、実験から得られる事実を数值解析 により補完して知見を明確化すると同時に、数值 解析における境界条件や界面現象のモデリング を実験事実に照らして適切化することにある。

本稿では、これらの取り組みを具体的事例に沿 って紹介するとともに、関連する研究課題につい て展望したい。

\section{3. 推進薬の流動：動き}

\section{1 再使用ロケット実験機 (RVT)}

宇宙科学研究所(JAXA/ISAS)では、再使用型宇 宙輸送機(RLV)の実現へ向け、Fig.2 に示すような、 液体酸素と液体水素を推進薬とする、圧力供給方 式の小型エンジンを搭載したロケット実験機を 製作し、比較的短秒時の垂直離着陸飛行試験を反 復することで、関連技術開発の促進と研究課題の 抽出を行ってきた。一連の試験では、比較的低高 度の放物飛行も検討されたが、その際、横風によ り誘起される小さな加速度でも、タンク内の推進 薬が大摇動する䀣念があった。液体摇動(スロッ シング)は機体姿勢制御に有害なだけでなく、タ ンク底部に気相(アレッジガス)が到達して大量に 


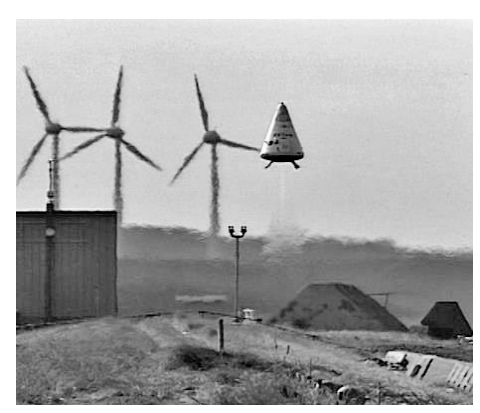

(a) Flight demonstration (RVT-9 in 2003).

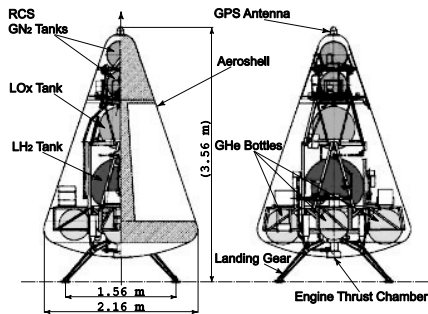

(b) Perspective drawing of vehicle.

Fig.2 Reusable rocket Vehicle Test : RVT ( JAXA/ISAS )

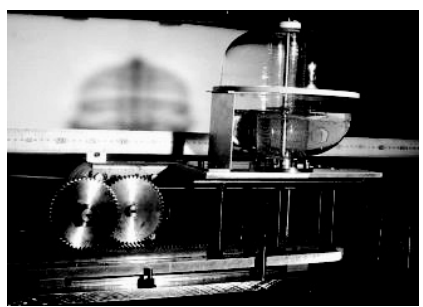

Fig.3 Electrical exciter for sloshing test.
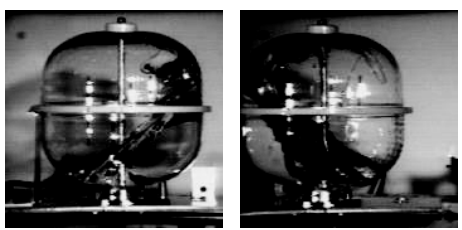

(a) Experiment
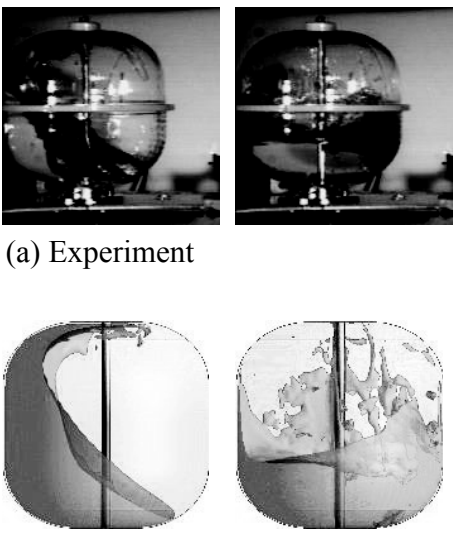

(b) Computation

Fig.4 Sloshing in the model tank of RVT without anti-slosh devices[6].

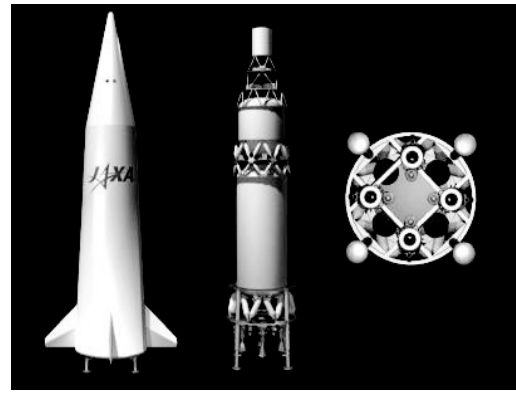

(a) Configuration of vehicle (GC).

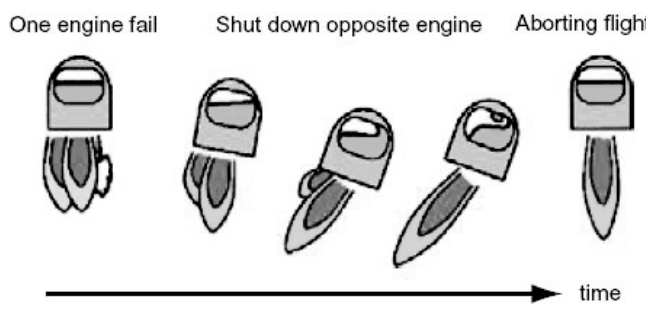

(b) Initial operation of aborting operation.

Fig.5 Reusable SoundingRocket : RSR ( JAXA/ISAS )

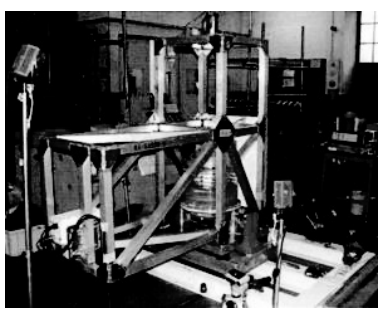

Fig.6 Hydraulic exciter for sloshing test.
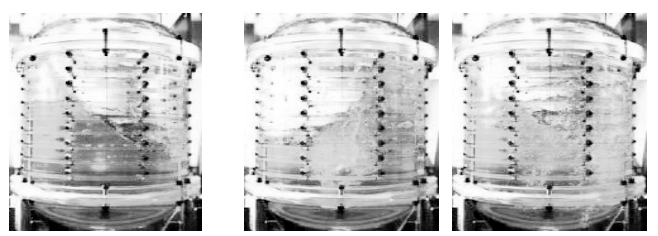

(a) Experiment
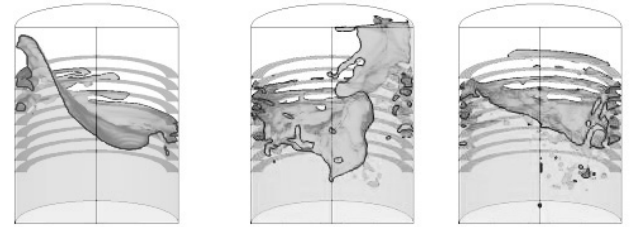

(b) Computation

Fig.7 Sloshing in the model tank of RSR with multiple baffles[8]. 
供給配管へ混入すると、エンジンの再着火に失敗 し、機体喪失に陥る危険があった。

そこで筆者らは、Fig.3 に示すような電動加振 機を製作して、模型タンク加振実験を試みた。界 面張力と粘性力の影響を無視し、慣性力と加速度 力で作られるフルード $(F r)$ 数の一致に基づく相似 則を仮定すれば、模型タンク内部で観察された液 体摇動を、実機タンク内部の現象に換算できる。

実験結果の一例を、並行して実施した数值解析 結果と共に Fig.4に示す。計算では、格子幅より 細かく分裂した気泡や飛沫について比較はでき ないものの、液体摇動の振幅や砕波のタイミング などに注目すると、実験をよく再現できている。 ことから、界面を 1 格子幅以内で捕獲する CIP-LSM と物体適合格子を用い、動的に変化する 加速度環境で、三次元的に大変形し大移動する界 面挙動を、かなり正確に模擬できる可能性を確認 できた。

\section{2 再使用観測ロケット(RSR)}

同所は、RVT の発展計画として、高層大気観測 や長秒時無重力実験をミッションとする再使用 観測ロケット(RSR)を提案[7]している。Fig.5 (a) に示す機体は、地上からの加速上昇の後、エンジ ンを停止して高度約 $120 \mathrm{~km}$ に達する弾道飛行と 大気圈への再突入を行った後、エンジンを再着火 して減速下降し、所定の着陸点へ垂直着陸する。 推進系については、中断帰還(アボート)を含む多 様な運用形態に対応するため、ポンプ供給方式の 液酸液水エンジンを 4 系統クラスタ化した宂長 系が組まれている。

万一、加速上昇中に 1 系統のエンジン故障が検 知された場合、Fig.5(b)に示すように、故障系統 と対称に配置された系統のエンジンも停止させ たうえで、残り 2 系統で地上帰還のための飛行を 継続する。その場合、故障発生から対系統エンジ ンの停止までの間には、推力のミスアライメント によって機体姿勢が大きく変動し、横方向加速度 が発生するため、推進薬タンク内では大振幅のス ロッシング発生が懸念されている。

筆者らは、JAXA と三菱重工業侏の協力を得て、 実機タンク内に艤装される邪魔板の液体摇動減 衰効果の評価を行うべく、Fig.6 に示すような油 圧加振機を用い、模型タンク加振実験を試みた $[8]$ 。

実験結果の一例を、並行して実施した数值解析 結果と共に Fig.7 に示す。リング状邪魔板の内縁
付近に立ち上がる波頭の形状や、その後に多数の 気泡が液体内部に取込まれる様子が計算でも再 現された。また、数周期の摇動を経た後の液面傾 斜についても、実験結果との良い一致が確認され、 複数枚の邪魔板によるスロッシング抑制効果を 適切に評価できた。

\section{3 基幹ロケット上段推進系 ( $\mathrm{H}-\mathrm{IIA})$}

JAXAが中心となって開発された基幹ロケット (H-IIA)の上段を Fig.8 に示す[9]。この機体に搭載 されるエンジン(LE-5B)は多数回着火機能を有し、 様々なミッション要求に対応できる。その一方、 燃焼を一旦停止して機体が低重力環境を経験す る慣性飛行の数十分間、エンジンの再着火に備え て、推進薬をタンク底部の吸引口付近に静定(リ テンション)させなくてはならない。また、推進 薬にキャビテーション余裕を持たせるため、再着 火に先立ってタンク内へ加圧ガスを噴射する昇 圧操作(再着火前過渡加圧)が必要とされる。

H-IIA 初号機の飛行では、上段推進系での推進 薬管理の妥当性を検証す心゙く、タンク内に多数の 液相センサを配置し、推進薬挙動が詳細に調べら れた。また、再々着火に先立つエンジン始動シー ケンスを実証すべく、ペイロード放出後の残留推 進薬を利用した軌道上実験も実施され、その間、 液体水素タンク内の様子が CCD カメラにより可 視化された。ところが、各液相センサからの出力

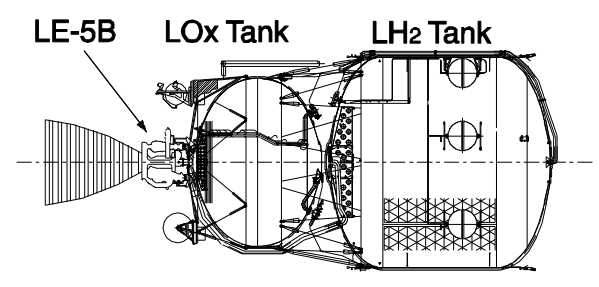

Fig.8 Perspective drawing of H-IIA Upper Stage[9].

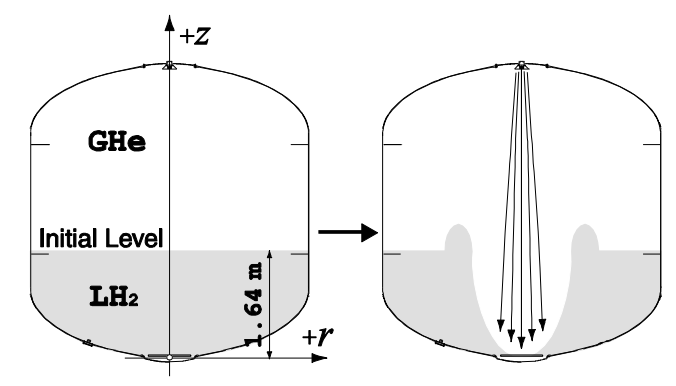

Fig.9 Schematic drawing of gas penetration during coasting flight[9]. 

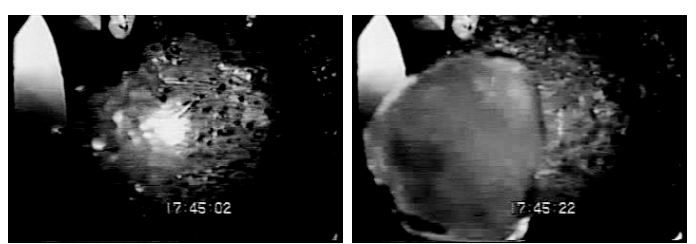

Fig.10 Dynamic behavior of liquid hydrogen, visualized during the pressurization in the extended engineering experiment[9].

Left : Wavy surface and following atomization. Right: Liquid drop coming up to the top.
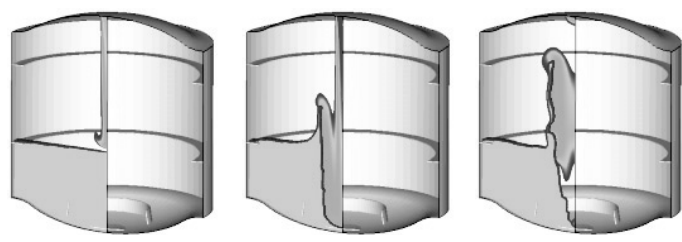

Fig.11 Computed deformation of liquid hydrogen[9].

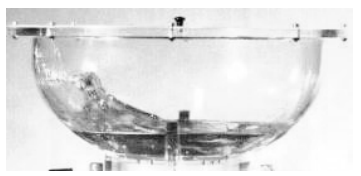

(a) Experiment

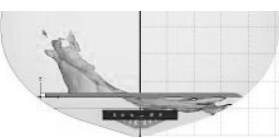

(b) Computation
Fig.12 Sloshing with small residual (model scale)[10].
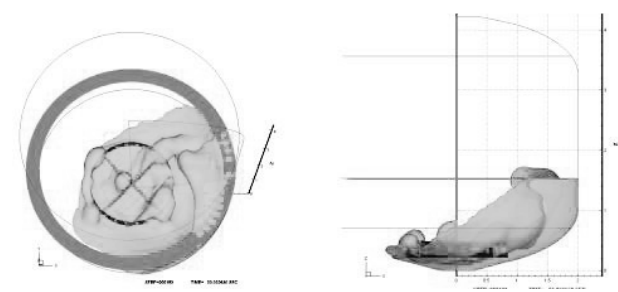

Fig.13 Computed deformation of liquid hydrogen during coasting flight of $\mathrm{H}$-IIA upper stage induced by small disturbance (flight scale).

を総合した結果、Fig.9 に示すように、再着火前 過渡加圧の開始後、液体水素タンクの前方ドーム 頂部に位置するディフューザを通じて噴射され た加圧ガスが、液面へ強く吹き付け、さらに液相 をタンク底部まで貫入していたことが示唆され た。実際、Fig.10に示す再々着火予備実験中の取 得映像からも、加圧ガスの噴流が液面に吹き付け る様子が明瞭に捉えられており、ディフューザの
ガス拡散性能が不十分であることが判明した。

本不具合事象の事後評価として、筆者らは、再 着火前過渡加圧時の液体水素タンク内流れ場の 数值解析を行った。計算では、タンク形状が一部 簡略化されているものの、加圧ガスの流量と温度、 系に加わる加速度などの条件は実際の飛行デー タと一致させ、風洞試験で計測されたディフュー ザ下流の速度分布を基に加圧ガスの流入境界条 件を与えた。

Fig.11 に示す計算結果からは、噴射された加圧 ガスの大部分が液面に吹き付け、その後、深く液 体水素を貫入する様子が再現されており、ディフ ユーザ下流の速度分布を改善する必要があるこ とが確認された[9]。

その後、H-IIA 2 号機の打上げに先立ち、ガス 拡散性能を向上させた改修型ディフューザを用 いた場合の過渡加圧時の数值解析も実施し、その 健全性を評価したことを付記する。

\section{4 基幹ロケット上段推進系 (高度化 H-IIA)}

現在、基幹ロケットの多用途化を目的として進 められている H-IIA 上段推進系の高度化では、上 段エンジン $(\mathrm{LE}-5 \mathrm{~B})$ の再々着火が計画されており、 再着火から再々着火に至る長秒時慣性飛行中の タンク内残推進薬量は、タンク容積に対して数\% にまで少なくなる。そのため、機体姿勢変化等に よる推進薬の過大なスロッシング発生や、再々着 火時のアレッジガス供給配管混入が懸念され、こ れらを防止するための対策が求められている。

この課題に対しては、Fig.12(a)に示すように、 まず、数值解析の妥当性を検証するための模型夕 ンク加振実験を実施した[10]。具体的には、タン クの邪魔板配置の再検討を行い、水を用いた模型 タンク加振実験を実施。Fig.12(b)に示すように、 対応する数值解析結果が、広範な条件下において 実験結果と一致することを確認した。

続いて、Fig.13に示すように、上段推進系の慣 性飛行時における実機スケールでの数值解析を 実施し、低重力環境で外乱加速度が印加された際 の液面挙動を予測し、タンク内邪魔板配置の妥当 性を評価しつつある。

また、3.3 項で述べられた実績を活かし、基幹 ロケット高度化の実飛行時には、タンク内推進薬 挙動を可視化することにより、実現象の理解と数 值解析手法の検証に益するデータ取得が計画さ れている。 


\section{5 軌道間輸送機 (将来輸送系)}

現状、基幹ロケット(H-IIA)上段の慣性飛行時に おける推進薬のリテンションには、ヒドラジンス ラスタによる機軸方向加速度の印加が行われて きた。また、上段推進系高度化では、ヒドラジン 節約のために水素タンクからの放圧(ベント)ガス によるリテンションを採用する計画である。

しかしながら、さらなる将来、極低温上段推進 系で超長秒時ミッションを行う場合には、無効推 進薬の最少化が至上命題となることから、ベント リテンションの採用も難しいと判断される。

一方、軌道上で長期間に亘って運用される人工 衛星の推進薬タンクでは、界面張力と濡れ性を利 用した推進薬捕獲デバイスが広く採用されてい る。大型の極低温推進薬タンクへの適用例は未だ 存在しないが、これが実現されれば、リテンショ ン加速度の印加により消費される無効推進薬の 低減に有効であると期待される。

この研究課題に対して筆者らは、Fig.14 示寸落 下塔(東京大学、津江・中谷研究室に設置)を用い、 重力がステップ的にほぼ消失した環境で、界面張 力と濡れ性に駆動される自由表面流の観察実験 を実施した[11]。実験結果の一例を、並行して実 施した数值解析結果と共に Fig.15に示す。

実験結果からは、固体壁面上で濡れが進行し、 その接触線変位が界面上を伝播していく様子が 見て取れる。また、進行濡れと界面張力波の伝播 について、計算結果と観察された実験結果の間に 良好な一致を認めることができる。界面厚を排除 した今回の計算でも、界面張力波の伝播とそれに 伴う界面変形を、接触線の変位までを含め、安定 かつ精度良く模擬できると評価した。

加えて、比重差が殆ど違わない非混和性 2 液体 を用いた低ボンド $(B o)$ 数環境を模擬した実験を 実施し、併せて数值解析も試みている。Fig.16に 示寸結果からは、界面張力と濡孔性を利用して捕 獲される流体の液面形状を、計算でも良好に再現 可能であることが確認された。今後、人工衛星な らびに上段推進系に採用される推進薬捕獲デバ イスの形状検討を進める計画である。

\section{4. 推進薬の熱流動：動き + 熱 + 相変化}

極低温推進系のタンク内部は、極低温液体と 比較的高温のアレッジガスが共存する系であり、 機体姿勢変化や推力変動に伴うスロッシングが
発生すると、気液間の熱交換が促進され、タンク 圧を制御するのが難しくなる。従って、推進薬の 流動だけでなく、相間伝熱や相変化までを含め、 スロッシングに伴う圧力変動を適切に予測する ことも重要である。

\section{1 非等温スロッシングとタンク圧制御}

一般に、極低温推進系の設計において、ターボ ポンプで一旦昇圧された極低温推進薬の一部を
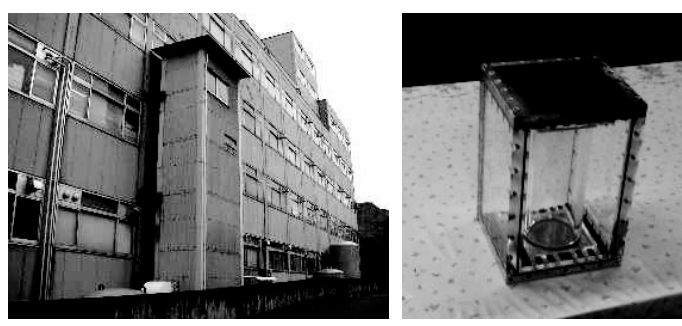

Fig.14 Drop tower (left) and test cylinder (right)
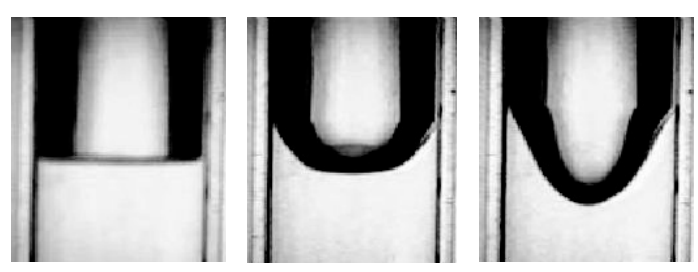

(a) Experiment
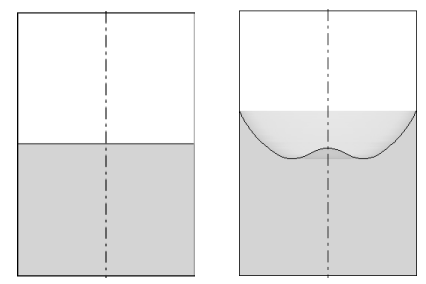

(b) Computation

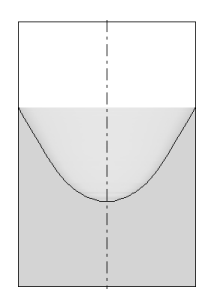

Fig.15 Liquid motion in a cylinder driven by capillary force. Ethanol and poly-acrylate resin, $80 \mathrm{~mm}$ in diameter[6,11].

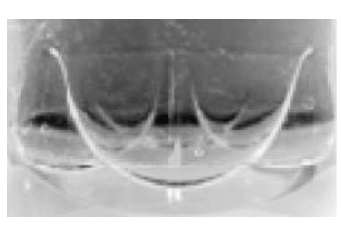

(a) Experiment

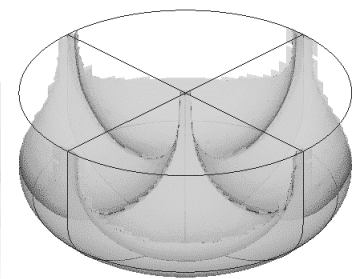

(b) Computation
Fig.16 Liquid acquisition with vanes under low $B o$ number condition[10]. 


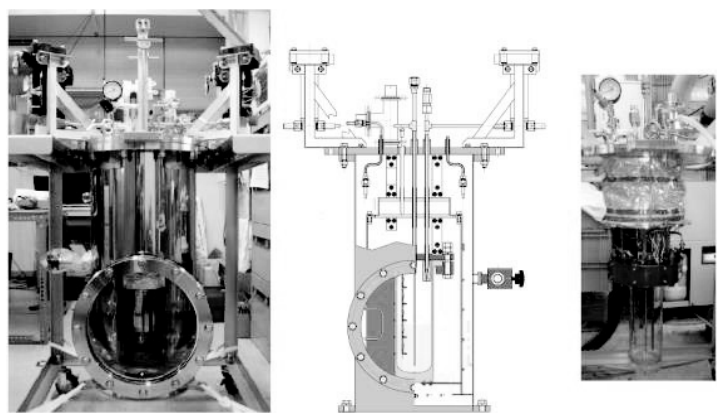

Fig.17 Super-insulated cryostat for sloshing test Assembly (left), section view (center) and test vessel made of polycarbonate (right) .

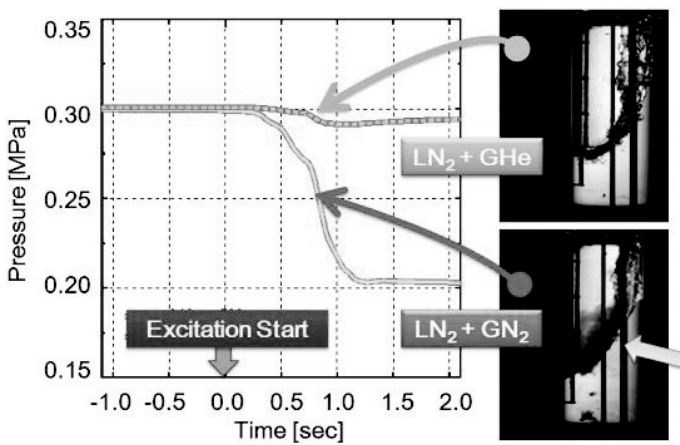

Fig.18 Dynamic motion of liquid nitrogen in a cylinder pressurized with gaseous nitrogen or helium and induced changes in pressure.

熱交換器で昇温させてタンクに戻す「同種加圧」 方式を採用すると、加圧系統の簡素化に伴う機体 重量の利得がある反面、熱力学的に非平衡一成分 系となるタンクの圧力制御が難しくなる。タンク 圧力の急降下は、キャビテーション余裕の低下に 直結し、ターボポンプ吸込性能の悪化を招くなど、 推進系にとって有害である。

この研究課題に対して筆者らは、Fig.17に示す 真空断熱槽(クライオスタット)を製作し、内部に 設置した小型透明の密閉容器に極低温液体と常 温気体を封入して、スロッシング実験を行った。 具体的には、真空断熱槽を電動加振機に搭載し、 水平方向に様々な非定常加速度を与えることで、 液面変形が線型的応答を呈する微小な場合から、 砕波を生じる大規模な場合まで、容器内部での熱 交換と相変化に起因する圧力変動を計測した。同 時に、真空断熱槽の観察空を通じて容器内部の液

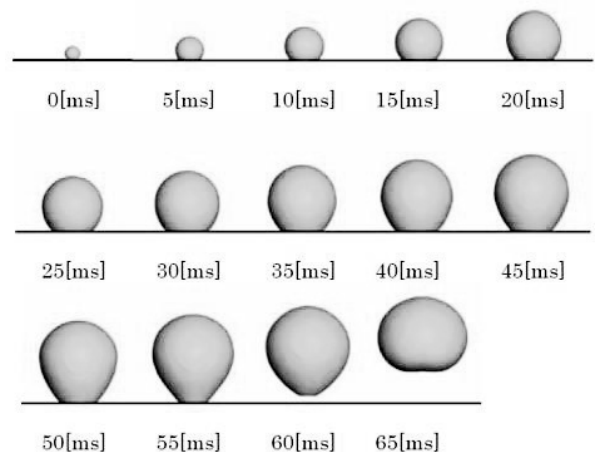

Fig.19 Bubble growth and departure[13].

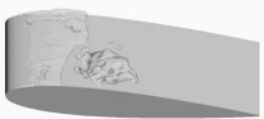

$\sigma=1.6$

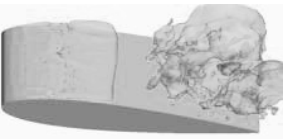

$\sigma=0.6$

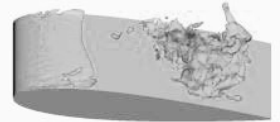

$\sigma=1.2$

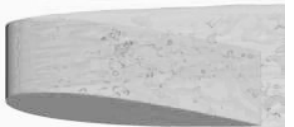

$\sigma=0.2$
Fig.20 Cavitation around NACA0015 airfoil[14]. Computed by interface capturing method $($ CIP-LSM) : Attack angle $=8$ deg.

面挙動を高速度撮影し、加速度に駆動された自由 表面流の動力学的挙動と圧力変化の相関を整理 するとともに、その発生機序を伝熱学的に説明す ることを目指している。

実際、液体窒素を用いた極低温スロッシング実 験では、気体窒素による同種加圧の条件を課した 場合、Fig.18に示すように、スロッシングに伴っ て気体窒素が急激に凝縮する様子が観察された。 気体へリウムによる異種加圧の場合に比べて、大 幅な圧力降下の発生が認められた[12]。

\section{2 相変化モデルの構築へ向けて}

このような圧力変化までを含め、数值流体解析 により模擬するためには、乱流熱伝達と相変化が 適切に考慮されるべきである。

近年、界面捕獲法に基づく自由表面流数值解法 に適した相変化モデルが考案された(梅村ら)[13]。 現在までに、筆者らは、Fig.19に示す沸騰気泡の 
離脱現象[13]や、Fig.20に示すキャビテーション 流れ[14]への適用を試み、対応する実験結果との 比較を通じて、モデルの妥当性を検証しつつある。

しかし現状では、特に砕波を伴う激しい液体摇 動の場合、界面近傍の温度境界層を解像できず、 圧力降下の促進効果を定量的に予測できるには 至っていない。一般的に見て、相変化との連成ま でを適切に考慮した自由表面流の数值解析は発 展途上である。

\section{5. まとめ}

様々な加速度環境における推進薬管理技術の 確立へ向け、実験による知見の蓄積と、自由表面 流解法 (CIP-LSM)の改良を通じた取り組みを紹 介した。静的あるいは動的な加速度を受けて気液 間の比重差に駆動される流れと、低重力環境で界 面張力と濡れ性に駆動される流れについて、動的 な液面変形に注目して計算結果と実験データを 比較したところ、何れの場合でも、両者の間に良 好な一致を確認できた。濡れ性モデルの高度化、 乱流モデルや相変化モデルの組み込みに加え、移 動境界熱流動現象について手法の妥当性を評価 する更なる検証などを慎重に進めることが、今後 の課題である。

推進薬管理技術の構築にあたっては、流体力学 や伝熱学などの様々な学理を、極低温、超高圧、 微小重力といった極限的条件下に展開し、そこで 獲得した知見を人工物の設計に反映させなくて はならない。そのためには、分析技術(分析科学) と統合技術(設計科学)の両方が必要であり、数值 流体解析をはじめとする計算力学的手法の援用 が強く期待されている。同時に、現象の理解とモ デリング、および、解析技術を検証するため、実 験が果たす役割は拡がっており、一層重要度を増 していることを強調したい。

\section{参考文献}

[1] Reynolds, W. C. and Statterlee, H. M., Liquid propellant behavior at low and zero g., The Dynamic Behavior of Liquids in Moving Containers, Abramson, H. N. (ed.), NASA SP-106, 387-449(1966).

[2] Antar, B. N. and Nuotio-Antar, V. S., Fundamentals of Low Gravity Fluid Dynamics and Heat Transfer, CRC Press(1993) (ISBN 0-8493-8913-5).
[3] Yabe, T. and Takei, E., A new higher-order Godnov method for general hyperbolic equations, J. Phys. Soc. Japan, Vol.57, 2598-2601(1988).

[4] Kunugi, T., MARS for multiphase calculation, Computational Fluid Dynamics Journal, Vol.9(1) (2000).

[5] Sussman, M., Smereka, P. and Osher, S., A level set approach for computing solutions to incompressible two-phase flow, J. Comput. Phys., Vol.114, 146-159(1994).

[6] Himeno, T., Negishi, H., Nonaka, S., Inoue, C., Watanabe, T. and Uzawa, S., Numerical Analysis of Free-surface Flows under Various Conditions in Acceleration (Improvement of CIP-LSM : CIP-based Level Set \& MARS), Trans. JSME Ser.B, Vol.76(765), 778-788(2010).

[7] Working Group of Reusable Sounding Rocket, Proposal of Reusable Sounding Rocket, Institute of Space and Astronautical Science, Japan Aerospace Exploration Agency (ISAS/JAXA), (2006), (in Japanese)

[8] Himeno, T., Watanabe, T., Nonaka, S., Naruo, Y., Inatani, Y. and Aoki, H., Numerical and Experimental Investigation on Sloshing in Rocket Tanks with Damping Devices, AIAA 2007-5557(2007).

[9] Himeno, T., Konno, A., Tsuboi, M., Fukuzoe, M., Kitayama, O. and Watanabe, T., Numerical Investigation of Liquid Behavior in the Propellant Tank of H-IIA, AIAA 2002-3987(2002).

[10] Kinefuchi, K., Saito, Y., Yamanishi, N., Sarae, W.,Okita, K., Tani, N., Kobayashi, H., Himeno, T., Aoyama, T. and Kitayama, O., Proceedings of the 56th Conference on Space Science and Technology. JSASS, No.1A04 (2012).

[11] Himeno, T., Watanabe, T. and Imai, R., Numerical Analysis of Free Surface Flows Driven by Interfacial Tension Effect, Journal of the Japan Society of Microgravity Application, Vol.23(2), 99-105(2006).

[12] Himeno, T., Sugimori, D., Ishikawa, K., Umemura, Y., Uzawa, S., Inoue, C., Watanabe, T., Nonaka, S., Naruo, Y., Inatani, Y., Kinefichi, K., Yamashiro, R., Morito, T. and Okita, K., Heat Exchange and Pressure Drop Enhanced by Sloshing, AIAA 2011-5682(2011).

[13] Umemura, Y., Himeno, T. and Watanabe, T., Numerical Simulation of Bubble Growth and Departure on Heat Transfer Surface, J. Jpn. Soc. Microgravity Appl. Vol. 29(1), 2-7(2012).

[14] Ishikawa, K., Umemura, Y., Himeno, T., Watanabe, T., Tani, N., Terashima, H. and Koshi, M., Numerical Analysis on Unsteady Cavitation by Direct Interface Tracking Approach, Trans. JSASS Aerospace Tech. Japan, (accepted) 